\title{
Article
}

\section{"Relationship between carbon stocks and structural diversity in humid and subhumid tropical forest of Mexico "}

Martinez, Jose, Camara, Luisa, Tigar, Barbara and Castillo, Ofelia Available at http://clok.uclan.ac.uk/15652/

Martinez, Jose, Camara, Luisa, Tigar, Barbara ORCID: 0000-0001-6037-3544 and Castillo, Ofelia (2016) "Relationship between carbon stocks and structural diversity in humid and subhumid tropical forest of Mexico ". Écoscience, 22 (2-4). pp. 125-131. ISSN 1195-6860

It is advisable to refer to the publisher's version if you intend to cite from the work. http://dx.doi.org/10.1080/11956860.2016.1169384

For more information about UCLan's research in this area go to http://www.uclan.ac.uk/researchgroups/ and search for <name of research Group>.

For information about Research generally at UCLan please go to http://www.uclan.ac.uk/research/

All outputs in CLoK are protected by Intellectual Property Rights law, including Copyright law. Copyright, IPR and Moral Rights for the works on this site are retained by the individual authors and/or other copyright owners. Terms and conditions for use of this material are defined in the policies page. 


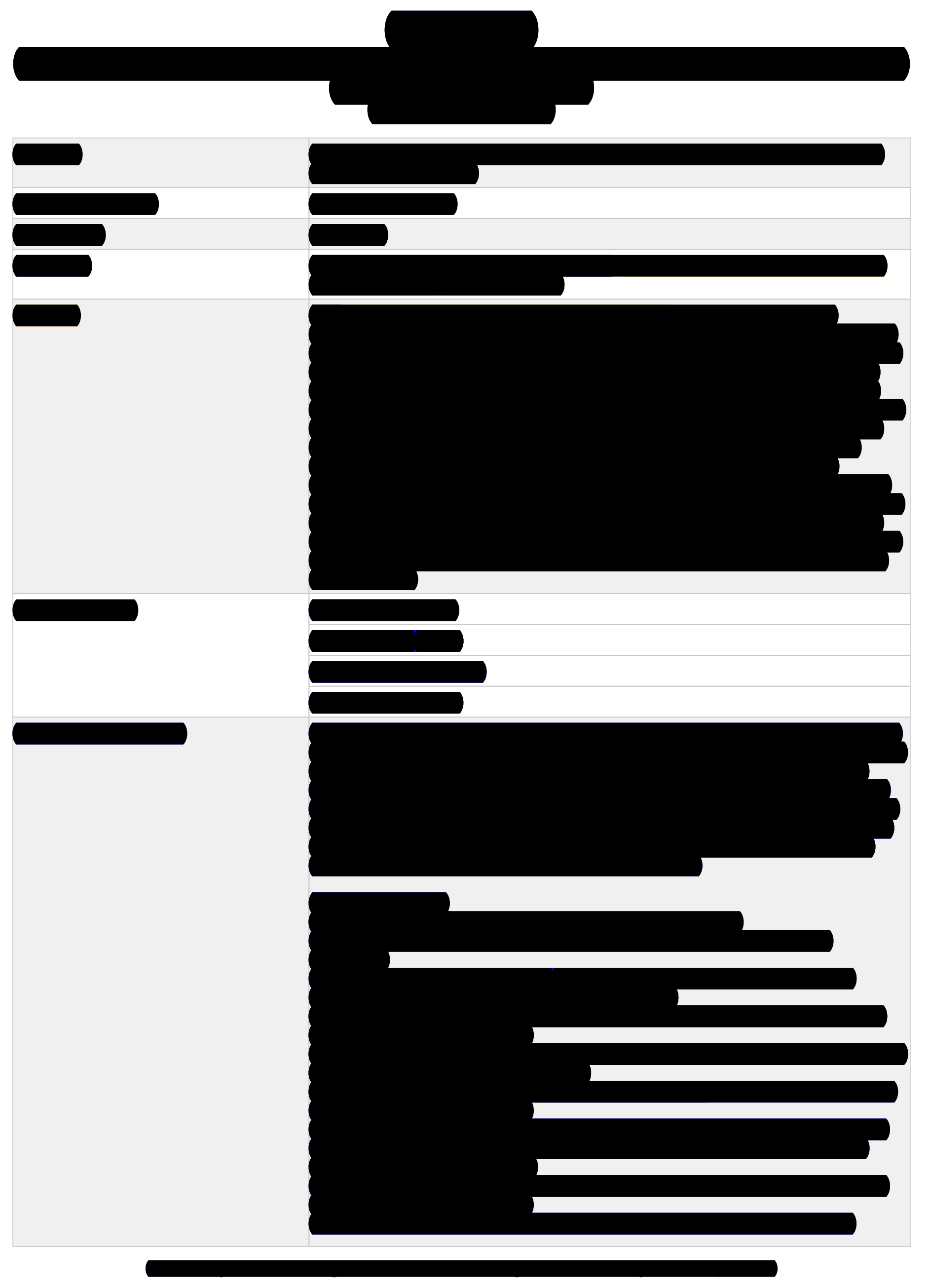




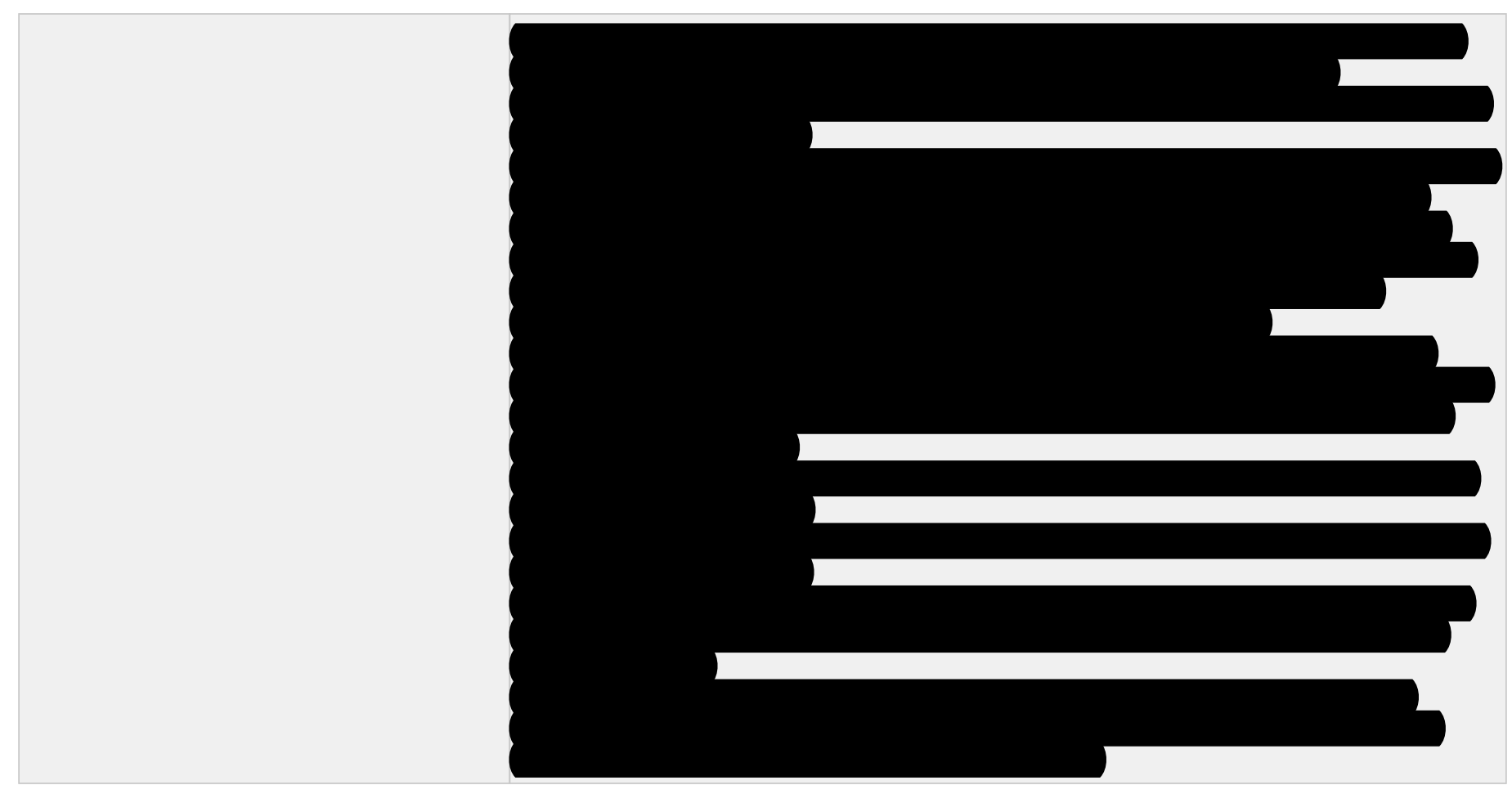




\title{
Mexico
}

\author{
José Luis Martínez-Sánchez ${ }^{1 *}$, Luisa Cámara ${ }^{1}$, Barbara J Tigar² and Ofelia Castillo \\ 1. División de Académica de Ciencias Biológicas, Universidad Juárez Autónoma de Tabasco
}

Av. Universidad s/n, Col. Magisterial, Villahermosa, Tab. México. 86200. Phone: 52(993)1654937, Fax: 52(993)3544308.

2. School of Health Sciences, Liverpool Hope University, Hope Park, Liverpool, LD16 9JD, UK

*Corresponding author: jose.martinez@ujat.mx

\begin{abstract}
Tree structure may strongly influence carbon storage which currently plays a key role in global carbon cycling. Two structural-diversity and two biodiversity indexes and carbon stocks were determined at eight humid and sub-humid tropical forest sites between 20-120 yrs-old in southeastern Mexico. The dbh of all trees $>10 \mathrm{~cm}$ was measured and species were identified in 131 randomly located plots of different sizes. Results for the number of species (S), Shannon $(H)$, biomass-species (BS) and abundance-biomass-species (ABS) indexes were related to $\mathrm{Mg}$ $\mathrm{C} \mathrm{ha}^{-1}$ and the age of the sites. Values found were: S, 27-109; $H^{\prime}$, 3.9-5.31; BS, 7.39-16.0; ABS, 9.87-18.2; $\mathrm{Mg} \mathrm{C} \mathrm{ha-1,} \mathrm{39.7-130.7.} \mathrm{The} \mathrm{relationships} \mathrm{between} B S$ and $A B S$ to $C$ and the age of the sites were linear and positive, showing that stand structure directly influenced carbon storage. The relationship between site age and $C$ was remarkably high $\left(R^{2}=0.79\right)$. Humid forests showed higher values of $C$ than the sub-humid forests (104.4 vs. $70.6, t=2.07, P=0.04$ )
\end{abstract}


but their structural diversity was similar (BS, 11.25 vs. $8.3, P=0.134 ; A B S, 13.9$ vs. $10.6, P=$ 0.135). It is concluded that forestry management (of tree diameter) may be a factor that can favor more carbon storage in secondary forest regrowth as it starts to reach maturity.

Keywords: aboveground biomass, arboreal community, global warming, natural regeneration, structural indexes, sub-humid forest.

\section{Résumé}

À l'heure actuelle les stocks de carbone des communautés forestières sont d'une grande importance mondiale, mais la structure des arbres peut influencer de manière significative. Dans cet article, deux indices de diversité structurelle et deux niveaux de biodiversité ont été associés à des stocks de carbone dans huit forêts tropicales et sous 20 à 120 ans dans le sud du Mexique. DHP de tous les arbres> $10 \mathrm{~cm}$ de diamètre a été mesurée, et l'espèce a été identifiée dans 131 parcelles de différentes tailles placés aléatoirement. La richesse en espèces (S), indice de Shannon $\left(\mathrm{H}^{\prime}\right)$, l'indice de diversité structurelle biomasse-espèces (BS) et de l'abondance-biomasse-espèces (ABS) avec des magasins connexes mg $C$ ha-1 (C) et l'âge des sites. Les valeurs trouvées sont les suivantes: S, 27-109; H ', 3.9 à 5.31; BS, de 7,39 à 16,0; ABS, de 9,87 à 18,2; $M g C$ ha ${ }^{-1}$, de 39,7 à 130,7. Les relations entre $B S$ et $A B S$ avec $C$ et l'âge des sites étaient tous linéaire et positive. Le rapport de l'âge du site avec C était significativement plus élevé $\left(R^{2}=79,6\right)$. Les forêts tropicales ont montré des valeurs plus élevées de forêts sub-humides $C(104,4$ vs $70,6, t=2,07, p=0,04)$, mais sa diversité structurelle était similaire (BS, 11.25 contre $8,3, P=0,134$; $A B S, 13,9$ vs. $10,6, P=0,135$ ). Il est conclu que la gestion sylvicole (diamètre Woodland) peut être un facteur favorisant le stockage du carbone dans le stade de la maturité de la végétation.

Mots-clés: biomasse aérienne, la communauté arboricole, le réchauffement climatique, la régénération naturelle, les indices structurels, forêts sub-humide. 


\section{Introduction}

Species diversity and arboreal structure are the main attributes that influence the community structure of forests (Magurran 1988) and hence may influence large scale carbon accumulation in humid forests over time. However anthropogenic activities can result in changes to structural components of vegetation which also influence carbon accumulation. Most studies of the relationship between biological diversity and carbon stocks or above-ground biomass (AGB) in arboreal ecosystems are based upon simple diversity indices such as species richness, Shannon Wiener index (1949), Simpson's index (1949), and Shannon's evenness (Magurran 1988), which either ignore tree structure or only consider it in a limited way. Alternative structural diversity indexes have been developed which give a more accurate estimate of the vertical and horizontal structure of the arboreal community (Lei et al. 2009; Wang et al. 2011; Tran et al. 2013). Species abundance, stem size and height all have a direct effect on the AGB of tropical forests (Tran et al. 2013). Therefore structural indexes show a better relationship with AGB than Shannon diversity index, because they assess diversity in $2.5 \mathrm{~cm}$ intervals of tree trunk diameter, and combine up to three variables of community structure such as abundance, biomass and species, rather than using one variable (Tran et al. 2013). In studies of mature arboreal communities, combining both diversity and arboreal structural indexes has given stronger relationships with above-ground biomass, than when using the index individually (Tran et al. 2013).

Carbon stocks $(C)$ in plant ecosystems contribute half of their standing biomass (AGB) (Pearson et al., 2005). Many studies have found a strong relationship between AGB or C stocks and biological diversity in ecosystems including grasslands (Tilman et al. 1996, Aarsen 1997, Hector et al. 1999) and temperate forests (Vila et al. 2005, Szwagrzyk and Gazda. 2007, Anning et al. 2008) and a particularly strong relationship in tropical humid forests (Bunker et al. 2005, Sharma et al. 2010, Vance-Chalcraft et al. 2010, Bora et al. 2013). All the above studies 
measured diversity via one of the commonly used indexes (Shannon-Weiner ( $\left.H^{\prime}\right)$ and Simpson's (D)) or species richness (S) and Shannon's evenness (E). However, the present study measures the relationship between $\mathrm{C}$ stocks and biological diversity using a structural index based upon the three community variables (abundance, AGB and $S$ by tree size) that are most likely to influence carbon storage.

AGB of tropical forests plays a key role in the conservation of organic carbon of the Earth's crust (Fearnside 2000; Sitch et al. 2008; Shevliakova et al. 2009) with old-growth forests considered to be the major carbon sinks (Alves et al. 1997). However, the role of secondary forests in carbon storage tends to be ignored despite the fact that they grow rapidly and can sequester large amounts of carbon in their biomass (Bongers et al. 2015). Although re-growth forest only contain $45-48 \%$ of the carbon stocks of old-growth forest their net carbon sequestration rate is up to 20 times higher (4.6 - 5.8 $\mathrm{Mg} \mathrm{Cha}^{-1}$ year $^{-1}$ ) (Pan et al. 2011; Brienen et al. 2015). It is therefore essential to incorporate the carbon sequestration potential of secondgrowth in future assessments of global carbon sinks (Bongers et al. 2015).

The aim of this work was to determine the relationship between the structural diversity of humid and sub-humid tropical forests of different ages and the amount of their carbon stored. As a hypothesis it was expected to find a positive relationship between structural diversity and the carbon stocks of the different aged stands of vegetation, and an increase in this relationship with increasing age of arboreal vegetation.

\section{Methods}

\section{Study area and data collection}

Eight humid and sub-humid forest sites were selected in southeastern Mexico, ranging from 20 to 120 years of age and including both natural regeneration and mature forests (Table I). There 
were three 20-60 year old sub-humid forest sites; three 25-60 year old humid forest sites and two 80-120 year old mature humid forest sites (Table I). No mature sub-humid forest sites were included because of its limited distribution, although the 60 year old site can be considered very close to maturity. Site ages were estimated using local knowledge and by determining the number of trees with $\mathrm{dbh}>80 \mathrm{~cm}$. The oldest sites had a higher number of thick stems and a larger dbh (see Table I). Three to 45 plot replicates of different sizes (Table I) were set up at random across each site, and at each plot the diameter of all tree trunks $>10 \mathrm{~cm}$ at dbh was measured and the species were identified.

(Table I near here)

\section{Estimation of carbon stock}

The AGB of each tree was calculated for each plot using the equation for humid (total annual rainfall $>3,500 \mathrm{~mm}$ ) and sub-humid (total annual rainfall 1,500 to $3,500 \mathrm{~mm}$ ) forests, and the lowest value of mean error according to Chave et al. (2005) (equation $1 \& 2$ below).

Tree height is difficult and imprecise to measure in closed-canopy forests. Hence, models involving only trunk diameter are usually preferred. However, models developed by Chave et al (2005) (equation 1 and 2) tested the relationship of the height of harvested trees against their above-ground biomass, and found that height was not as important a predictor of AGB as were dbh or wood density. This was based upon 27 datasets from Asia and America including Mexico comprising humid and sub-humid forest and secondary and old-growth forests comparable to those studied here (Chave et al. 2005).

Sub-humid tropical forest:

$$
\ln (A G B)=-1.562+2.148 \ln (D)+\ln (D)^{2}+\ln (D)^{3}+\ln (q)
$$


Humid tropical forest:

$$
\ln (A G B)=-1.302+1.98 \ln (D)+0.207(\ln (D))^{2}-0.0281(\ln (D))^{3}+\ln (q)
$$

Where:

$\mathrm{AGB}=$ above ground biomass

$\mathrm{D}=$ diameter at breast height $(\mathrm{cm})$

$q=$ wood density mean value of $0.6 \mathrm{~g} / \mathrm{cm}^{3}$

Equations 3 to 5 were used for particular groups and species of vegetation (Pearson et al. 2005).

Palms: Biomass $=6.666+12.826 \times$ height $0.5 \times \ln ($ Height $)$

Lianas: Biomass $=\exp (0.12+0.91 \times \log (B A$ at $d b h))$

Cecropia obtusifolia: Biomass $=12.764+0.2588 \times$ dbh2.0515

[5]

Carbon stock in each tree was calculated using formula 6 (Pearson et al.2005).

Carbon $=A G B$ * 0.5

\section{Diversity}

To facilitate comparison with other studies, species richness (S, total number of species ha-1) and Shannon's diversity index $\left(H^{\prime}\right)$ (Magurran 1988), were calculated for each site.

$$
H^{\prime}=-\sum_{i=1}^{S} p i x \log p i,
$$

Where: $p i$ is the portion of stems of the ith species. 


\section{Structural diversity}

Similarly, structural diversity indices were determined for each site using two indexes from Tran et al. (2013) the biomass-species diversity index (BS) and the abundance-biomass-species diversity index (ABS) (equation 8 and 9 below).

$$
B S=-\sum_{i=1}^{d}\{P A G B i \ln (P A G B i)+\mathrm{PS} i \ln (\mathrm{PS} i)\}
$$

Where:

PAGBi is proportion of AGB of diameter class ith, PSi is proportion of species in diameter class ith, $d$ is diameter classes.

$$
A B S=-\sum_{i=1}^{d}\{P A i \ln (P A i)+P A G B i \ln (P A G B i)+\mathrm{PS} i \ln (\mathrm{PS} i)\}
$$

Where:

PAi is proportion of stems in diameter class ith.

Diameter classes of $2.5 \mathrm{~cm}$ were used in all calculations.

\section{Statistical Analysis}

The relationships between the diversity indexes (S, $H^{\prime}, \mathrm{BS}$ and $\left.\mathrm{ABS}\right)$ and carbon stocks for the values obtained at the eight communities of different age were explored using Pearson's correlation coefficient $\left(\mathrm{R}^{2}\right)$. For means comparisons, a t-test assuming unequal variances was used. All analyses were completed using Statgraphics Centurion (Version 17.1.04, Statpoint Technologies, Inc., Warrenton, VA, USA). 


\section{Results \\ General characteristics of the study sites}

Table II shows the values for biological and structural diversity, and levels of carbon stock for the 8 forest communities of different age. Overall, the results suggest that the indexes of structural diversity and size of the carbon stocks increase with the age of the tree communities at the site. Species richness ranged from 27 to 109 species ha ${ }^{-1}$ and $H^{-1}$ varied between 3.7 and 5.31 with the highest diversity at the mature forest sites. The lowest $\mathrm{C}$ stock was in the 20 year old subhumid forest (39.7 Mg C ha-1) and the highest $\left(130.7 \mathrm{Mg} \mathrm{C} \mathrm{ha}^{-1}\right)$ in the 120 year old mature humid forest, with lower values for younger forests and highest values in older forests. The structural diversity indexes were particularly high with highest values in older forests. The BS indexes ranged from 5.69 to 16.0 and were consistently lower than the ABS indexes which ranged from 7.44 to 18.2 . BS and ABS varied according to the type and age of forest at the site.

(Table II near here)

\section{Relationship between diversity and carbon stock in different aged forests}

There was a positive correlation between species richness $(\mathrm{S})$ and Shannon index $\left(H^{\prime}\right)$ with carbon stock (Table III) $\left(\mathrm{R}^{2}, 0.58\right.$ and 0.51 for $\mathrm{S}$ and $H$ respectively against carbon stocks). $\mathrm{R}^{2}$ was 0.52 and 0.41 respectively for $S$ and $H^{\prime}$ against site age (Table III). Regardless of the age of sites, there was a positive correlation between BS and ABS and the amount of carbon stored (Figure 1) ( $R^{2} 0.49$ and 0.48 for $B S$ and $A B S$ respectively against carbon). There was also a positive correlation between $B S$ and $A B S$ and the age of site $\left(R^{2} 0.62\right.$ and 0.52 , for $B S$ and $A B S$ respectively against site age) (Figure 2). The $\mathrm{R}^{2}$ value for carbon stocks against the age of the site was remarkably high (0.79) suggesting a strong positive relationship (Figure 2). As the age of the sites increased, both their structural diversity and carbon storage increased (Figure 3). 
(Figure 1, 2 and 3 near here)

Comparison of biological \& structural diversity and carbon stocks between humid and sub-humid forests

Humid forests had higher mean values of species richness $(S)$ and Shannon index $\left(H^{\prime}\right)$ than subhumid forests $(S=76.6$. $\mathrm{sd}=21.5 ; \mathrm{S}=32.7, \mathrm{sd}=7.4$ humid forests and sub-humid forests respectively, $\mathrm{t}=4.17, \mathrm{P}=0.01)\left(H^{\prime}=4.8 . \mathrm{sd}=0.52 ; H^{\prime}=3.9, \mathrm{sd}=0.153\right.$ humid forests and subhumid forests respectively; $\mathrm{t}=3.83, \mathrm{P}=0.01$ ). There was no difference in their structural diversity $(B S=11.25 . \mathrm{sd}=3.4 ; \mathrm{BS}=8.3, \mathrm{sd}=3.14$; humid forests and sub-humid forests respectively, $t=1.25, P=0.134)(A B S=13.9 . s d=3.4 ; A B S=10.6, s d=3.6$; humid forests and sub-humid forests respectively, $t=1.28, P=0.135)$. Humid forests had higher mean carbon stock values than sub-humid forests (Figure 4).

(Figure 4 near here)

\section{Discussion}

Biomass accumulation or carbon sequestration in a forest stand is affected by external factors including climate and geographical location, and internal factors including species richness, population structure and diversity of stem size. Therefore, an index combining all internal factors may better represent the AGB to diversity relationship for a stand than one based on a single factor (Tran et al. 2013). A higher structure-species diversity indicates a greater variation in the stem size and number of species in each stem size class which results in a multilayered forest canopy allowing more efficient light infiltration (Tran et al. 2013). This may work in favor of 
natural or assisted regeneration of arboreal species and ecosystem productivity, and result in larger carbon stocks.

A positive relationship between structural indexes and carbon accumulation was confirmed along patches of vegetation of different ages (Figure 1). It can be seen that communities with higher structural diversity indexes (BS and ABS) also had larger carbon stocks. The highest structural diversity was found in mature or older forests (Figure 1), suggesting that these later successional stages account for a larger carbon stock (Figure 2) as a result of a higher variation in stem size in each diameter class of the community. This is in contrast to the younger successional stages which have more uniform stems sizes.

These results support the hypothesis that as forest structure increases with stand-age, there is a good potential for $\mathrm{C}$ sequestration in regenerating tropical forests, particularly in more humid regions (Figure 3). Forests with more structural diversity tend to hold more carbon in their vegetation. This has only been previously reported for mature tropical forest stands (Tran et al. 2013) and for aged forest stands in temperate regions (Lei et al. 2009; Wang et al. 2011).

The relationship between carbon stocks and biological and structural diversity indexes in tropical forests is seen in young aged stands as well as in climax communities at or near maturity. Age and arboreal growth are additional factors affecting community structure. For example, as the age of the forest increases, its structure also changes and is accompanied by increases in species richness (S), biomass (AGB) and the coefficient of variation of stem size distribution, in addition canopy structure becomes less homogeneous accompanied by an increase in the number of larger trees (Guariguata \& Ostertag 2001).

Structure is particularly important in arboreal communities because it may reflect the pattern of the relationship between species diversity and aerial biomass (Szwagrzyk \& Gazda 2007). For instance, in young secondary forests where many species and individual trees are still in the recruitment stage a unimodal pattern in the relationship between these two variables 
is more commonly seen (Healy et al. 2008; Vance-Chalcraft et al. 2010). In addition, it is important to mention that the $\mathrm{R}^{2}$ values for the BS correlations were slightly higher (49.1 and 61.9) than those obtained for ABS (48.0 and 52.3) (Figure 1 and Figure 2). This may suggest that arboreal biomass is a more important or sensitive variable in community structure than arboreal abundance, as BS includes tree biomass and ABS includes tree abundance. The same trend was found by Trans et al (2013), and may suggest that the BS index which lacks a measure of abundance should be used in preference to the ABS index which considers arboreal abundance.

Finally, an analysis of tropical communities with different annual rainfall (Table I) showed that trees in more humid environments store more carbon than those in sub-humid ones (Figure 3). This trend has been reported globally for humid forests which generally show higher productivity as indicated by higher species richness, diversity indexes and carbon stock, compared with sub-humid forests (Cascante \& Estrada 2001; Godínez-lbarra \& López-Mata 2002; Sarmiento et al. 2005; Basáñez et al. 2008; Maldonado-Sánchez \& Maldonado-Mares 2010; Martínez-Sánchez \& Cámara 2012). In this study, S, H' and carbon stock were also higher in humid than sub-humid forests. However, there were no differences in the structural indexes (BS and ABS) between humid and sub-humid forests.

There are some limitations to this study. Whilst the results were significant, there were only a small number of sites, and the slope and confidence intervals could easily change by the omission of one or other of the points. Therefore future work should increase the number of study sites and plots, in order to generate more robust data that will help inform the management of secondary forests and areas that are being remediated.

The results presented here show that the conservation and sustainable management of secondary tropical forests may lead to more efficient carbon storage. The higher the species and 
structural diversity that result from managing arboreal stem size suggest that regenerating arboreal communities have the potential to store high level of carbon and can provide important ecosystem and environmental services in tropical areas. By managing both the diameter of arboreal stem size and the species richness as regrowth forests recover towards maturity we would be able increase both the amount and speed of carbon sequestration. We can conclude that in sub-humid and particularly humid tropical forests, there is a relationship between structural diversity and carbon stocks. This information could be of great benefit to forest management planners wishing to achieve a higher carbon stock reserve in tropical regenerating forests.

\author{
Acknowledgements \\ Two anonymous reviewers are thanked for their comments and suggestions which helped us to \\ improve this article. Authors acknowledge the "Programa Integral de Fortalecimiento \\ Institucional" for the financial support for language translation, which is a public resource and it \\ is forbidden their use for political or personal purposes.
}




\section{References}

Aarsen, L.W., 1997. High productivity in grassland ecosystems: effected by species diversity or productive species? Oikos, 80: 182-183.

Alves, D., J.V. Soares, S. Amaral, E. Mello, S. Almeida, O. Fernandes, D.A. Silva \& A. Silveira, 1997. Biomass of primary and secondary vegetation in Rondônia, Western Brazilian Amazon. Global Change Biology,: 451-461.

An-ning, S., J. Tian-Zhen \& G. Jiang-Ping, 2008. Relationship between species richness and biomass on environmental gradients in natural forest communities on Mt. Xiaolongshang, northwest China. Forest Studies from China, 10: 212-219.

Basáñez A.J, J.L. Alanís \& E. Badillo, 2008. Composición florística y estructura arbórea de la selva mediana subperennifolia del ejido "El Remolino", Papantla, Veracruz. Avances en Investigación Agropecuaria, 12(2): 3-21.

Bongers, F., R. Chazdon, L. Poorter \& M. Peña-Claros, 2015. The potential of secondary forests. Science, 348 (6235): 642-643.

Bora, N., Arun Jyoti Nath, Ashesh Kumar Das. 2013. Aboveground Biomass and Carbon Stocks of Tree Species in Tropical Forests of Cachar District, Assam, Northeast India. International Journal of Ecology and Environmental Sciences, 38 (2): 97-106.

Brienen, R.J.W. et al., 2015. Long-term decline of the Amazon carbon sink. Nature, 519: doi:10.1038/nature14283.

Bunker, D.E., F. DeClerck, R.K. Bradford, J.C. Colwell, I. Perfecto, O.L. Phillips, M. Sankaran \& S. Naeem, 2005. Species Loss and Aboveground Carbon Storage in a Tropical Forest. Science, 310: 1029-1031.

Cascante, A.M. \& C.A. Estrada, 2001. Composición florística y estructura de un bosque húmedo premontano en el Valle Central de Costa Rica. Revista de Biologia Tropical, 49(1): 213-225.

Chave, J., C. Andalo, S. Brown, M.A. Cairns, J.Q. Chambers, D. Eamus, H. Folster, F. Fromard, N. Higuchi, T. Kira, J.P. Lescure, B.W Nelson, H. Ogawa, H. Puig, B. Riera \& T. Yamakura, 2005. Tree allometry and improved estimation of carbon stocks and balance in tropical forests. Oecologia, 145: 87-99.

Fearnside, P.M., 2000. Global Warming and Tropical Land-Use Change: Greenhouse Gas Emissions from Biomass Burning, Decomposition and Soils in Forest Conversion, Shifting Cultivation and Secondary Vegetation. Climate Change, 46: 115-158.

Godínez-lbarra, O. \& L. López-Mata, 2002. Estructura, composición, riqueza y diversidad de árboles en tres muestras de selva mediana subperennifolia. Anales del Instituto de Biología, Universidad Nacional Autónoma de México, Serie Botánica, 73(2): 283-314. 
Guariguata, M. \& R. Ostertag, 2001. Neotropical secondary forest succession: Changes in structural and functional characteristics. Forest Ecology and Management, 148:185-206.

Healy, C., N.J Gotelli \& C. Potvin, 2008. Partitioning the effects of biodiversity and environmental heterogeneity for productivity and mortality in a tropical tree plantation. Journal of Ecology, 9: 903-913.

Hector, A. et al., 1999. Plant diversity and productivity experiments in European grassland. Science, 294: 843-845.

Lei, X., W. Wang \& C. Peng, 2009. Relationships between stand growth and structural diversity in spruce-dominated forests in New Brunswick, Canada. Canadian Journal of Forestry Research, 39: 1835-1847.

Magurran, A.E., 1988. Ecological Diversity and Its Measurement. Princeton University Press, Princeton, NJ.

Maldonado-Sánchez, E.A. \& F. Maldonado-Mares, 2010. Estructura y diversidad arbórea de una selva alta perennifolia en Tacotalpa, Tabasco, México. Universidad y Ciencia, 26(3): 235-245.

Martinez-Sanchez, J.L. \& L. Camara. 2012. Is there a relationship between floristic diversity and carbon stocks in tropical vegetation in Mexico? African Journal of Agricultural Research, 7: 2584-2591.

Pan, Y., et al., 2011. A Large and Persistent Carbon Sink in the World's Forests. Science, 333: DOI: $10.1126 /$ science.1201609

Pearons, T, S. Walker \& S. Brown, 2005. Source book for land use, land use-change and forestry projects. Winrock International. US.

Sarmiento, G., M. Pinillos \& I. Garay, 2005. Biomass variability in tropical american lowland rainforests. Ecotropicos, 18(1):1-20.

Sharma, C.M., N.P. Baduni, S. Gairola, S.K. Ghildiyal \& S. Suyal, 2010. Tree diversity and carbon stocks of some major forest types of Garhwal Himalaya, India. Forest Ecology and Management, 260: 2170-2179.

Sitch, S., C. Huntingford, N. Gedney, P.E Levy, M. Lomas, S. L. Piao, R. Betts, P. Ciais, P. Cox, P. Friedlingstein, C.D. Jones, I.C. Prentice \& F. I. Woodward, 2008. Evaluation of the terrestrial carbon cycle, future plant geography and climate-carbon cycle feedbacks using five Dynamic Global Vegetation Models (DGVMs). Global Change Biology, 14 (9): 2015-2039.

Shevliakova, E., S W. Pacala, S. Malyshev, G.C. Hurtt, P.C.D. Milly, J.P. Caspersen, L.T Sentman, J.P. Fisk, C. Wirth \& C. Crevoisie, 2009. Carbon cycling under 300 years of land use change: Importance of the secondary vegetation sink. Global Biogeochemistry Cycles, 23: 1-16.

Szwagrzyk, J. \& A.Gazda, 2007. Above-ground standing biomass and tree species diversity in natural stands of Central Europe. Journal of Vegetation Science, 18: 555-562. 
Tilman, D., D. Woding \& J. Knops, 1996. Productivity and sustainability influenced by biodiversity in grassland ecosystems. Nature, 379: 718-720.

Tran, V.C, T.T. Nguyen, T.T.H. Do, C.K. Cao, H.Q Tran, T.L. Vu, V.D. Tran, \& S. Tamotsu, 2013. Relationship between aboveground biomass and measures of structure and species diversity in tropical forests of Vietnam. Forest Ecology and Management, 310: DOI.org/10.1016/j.foreco.2013.08.034.

Vance-Chalcraft, H.D., M.R. Willig, S.B. Cox, A.E. Lugo \& F.N. Scatena, 2010. Relationship between aboveground biomass and multiple measures of biodiversity in subtropical forest of Puerto Rico. Biotropica, 4: 290-299.

Vila, M., P. Inchausti, J. Vayreda, O. Barrantes, C. Gracia, J.J. Ibanez, \& T. Mata, 2005. Confounding factors in the observed productivity-diversity relationship in forest. Pages 65-86 in M. Scherer-Lorenzen, C. Korner, \& E.D. Schulze (eds), Forest Diversity and Function. Temperate and Boreal Systems. Vol 176. Ecological Studies. Springer, Berlin.

Wang, W., X. Lei, Z. Ma, D.D. Kneeshaw \& C. Peng, 2011. Positive relationship between aboveground carbon stocks and structural diversity in spruce dominated forest stands in New Brunswick, Canada. Forest Science, 57: 506-515. 
Table I. Characteristics and locations of the Mexican study sites. Age applies to all replicate sample plots. Proportion of stems $>80$ cm dap and maximum dbh are taken from the total number of sampled plots in each vegetation type.

\begin{tabular}{|c|c|c|c|c|c|c|c|c|c|}
\hline Site Name & Vegetation type & Age & $\begin{array}{l}\text { Proportion } \\
\text { of stems } \\
\text { (>80 cm } \\
\text { dap) }\end{array}$ & $\begin{array}{l}\text { Maximum } \\
\mathrm{dbh}(\mathrm{cm})\end{array}$ & Location & $\begin{array}{c}\text { Annual } \\
\text { average } \\
\text { temperature } \\
\left({ }^{\circ} \mathrm{C}\right)\end{array}$ & $\begin{array}{l}\text { Annual } \\
\text { average } \\
\text { rainfall } \\
(\mathrm{mm})\end{array}$ & $\begin{array}{c}\text { Number } \\
\text { (and size) } \\
\text { of } \\
\text { sampled } \\
\text { plots }\end{array}$ & $\begin{array}{c}\text { Sampled } \\
\text { area } \\
\text { (ha) }\end{array}$ \\
\hline La Cuchilla & $\begin{array}{l}\text { Sub-humid } \\
\text { tropical forest }\end{array}$ & 20 & 0 & 58.0 & $\begin{array}{l}17^{\circ} 47^{\prime} \mathrm{N}, \\
91^{\circ} 13^{\prime} \mathrm{W}\end{array}$ & 28.0 & 1,500 & $\begin{array}{c}25(10 x \\
10 \mathrm{~m})\end{array}$ & 0.25 \\
\hline Tila & $\begin{array}{l}\text { Humid tropical } \\
\text { forest }\end{array}$ & 25 & 0.7 & 38.0 & $\begin{array}{l}17^{\circ} 27^{\prime} \mathrm{N}, \\
92^{\circ} 21^{\prime} \mathrm{W}\end{array}$ & 22.1 & 3,450 & $\begin{array}{l}45(20 x \\
20 m)\end{array}$ & 1.8 \\
\hline Yumka & $\begin{array}{l}\text { Sub-humid } \\
\text { tropical forest }\end{array}$ & 40 & 1.2 & 137.5 & $\begin{array}{l}18^{\circ} 00^{\prime} \mathrm{N}, \\
92^{\circ} 49^{\prime} \mathrm{W}\end{array}$ & 26.9 & 2,159 & $\begin{array}{c}3(50 x \\
50 \mathrm{~m})\end{array}$ & 0.75 \\
\hline La Cuchilla & $\begin{array}{l}\text { Sub-humid } \\
\text { tropical forest }\end{array}$ & 60 & 1.7 & 115.0 & $\begin{array}{l}17^{\circ} 47^{\prime} \mathrm{N}, \\
91^{\circ} 13^{\prime} \mathrm{W}\end{array}$ & 28.0 & 1,500 & $\begin{array}{c}25(10 x \\
10 \mathrm{~m})\end{array}$ & 0.25 \\
\hline $\begin{array}{l}\text { Rieles de } \\
\text { San Jose }\end{array}$ & $\begin{array}{l}\text { Humid tropical } \\
\text { forest }\end{array}$ & 60 & 1.4 & 111.0 & $\begin{array}{l}17^{\circ} 19^{\prime} \mathrm{N}, \\
91^{\circ} 21^{\prime} \mathrm{W}\end{array}$ & 26.0 & 3,300 & $\begin{array}{c}13(30 x \\
30 \mathrm{~m})\end{array}$ & 1.17 \\
\hline $\begin{array}{l}\text { Veteranos de } \\
\text { la }\end{array}$ & $\begin{array}{l}\text { Humid tropical } \\
\text { forest }\end{array}$ & 60 & 0.5 & 144.0 & $\begin{array}{l}17^{\circ} 23^{\prime} \mathrm{N}, \\
91^{\circ} 21^{\prime} \mathrm{W}\end{array}$ & 26.0 & 3,300 & $\begin{array}{c}13(30 x \\
30 \mathrm{~m})\end{array}$ & 1.17 \\
\hline
\end{tabular}


148.0

$17^{\circ} 15^{\prime} \mathrm{N}$

26.5

3,500

$4(50 x$

1.0

Heroes

forest

Los Tuxtlas

Humid tropical

120

2.0

120.0

$91^{\circ} 24^{\prime} \mathrm{W}$

$50 \mathrm{~m})$

forest

$95^{\circ} 09^{\prime} \mathrm{W}$

25.1

$4,487 \quad 3(50 x$

0.75 $50 \mathrm{~m}$ ) 
Table II. Values of biological diversity and carbon stocks of eight arboreal communities of different ages in southeastern Mexico. Species richness (S), Shannon's index $\left(H^{\prime}\right)$, biomass-species diversity index (BS) and abundance-biomass-species diversity index (ABS).

\begin{tabular}{|c|c|c|c|c|c|}
\hline Site & $S$ & $H^{\prime}$ & $\mathrm{C}\left(\mathrm{Mg} \mathrm{ha}^{-1}\right)$ & BS & ABS \\
\hline 20-yr old Sub-humid forest & 30 & 3.7 & 39.7 & 5.69 & 7.44 \\
\hline 25-yr old Humid forest & 58 & 4.89 & 84.1 & 9.0 & 12.55 \\
\hline 40-yr old Sub-humid forest & 27 & 4.00 & 72.21 & 11.78 & 14.56 \\
\hline 60-yr old Sub-humid forest & 41 & 3.9 & 99.85 & 7.39 & 9.87 \\
\hline $60-y r$ old Humid forest & 66 & 4.55 & 99.4 & 9.12 & 11.16 \\
\hline $60-y r$ old Humid forest & 62 & 4.08 & 98.4 & 8.33 & 10.8 \\
\hline 80-yr old Humid forest & 109 & 5.31 & 109.5 & 13.8 & 17.0 \\
\hline 120-yr old Humid forest & 88 & 5.31 & 130.7 & 16.0 & 18.2 \\
\hline
\end{tabular}


Table III. Relationship between biodiversity indexes (S and $H^{\prime}$ ) and carbon stocks, and biodiversity indexes and stand age (yr), in eight humid and sub-humid forest sites in southeastern Mexico.

\begin{tabular}{llllll}
\hline & \multicolumn{2}{l}{ Carbon } & stocks & \multicolumn{2}{c}{ Age } \\
\hline & $\mathrm{R}^{2}$ & $\mathrm{P}$ & $\mathrm{R}^{2}$ & $\mathrm{P}$ \\
\cline { 2 - 5 } Species richness $(\mathrm{S})$ & 0.58 & 0.028 & 0.52 & 0.042 \\
Shannon index $\left(\mathrm{H}^{\prime}\right)$ & 0.51 & 0.046 & 0.41 & 0.08 \\
\hline
\end{tabular}



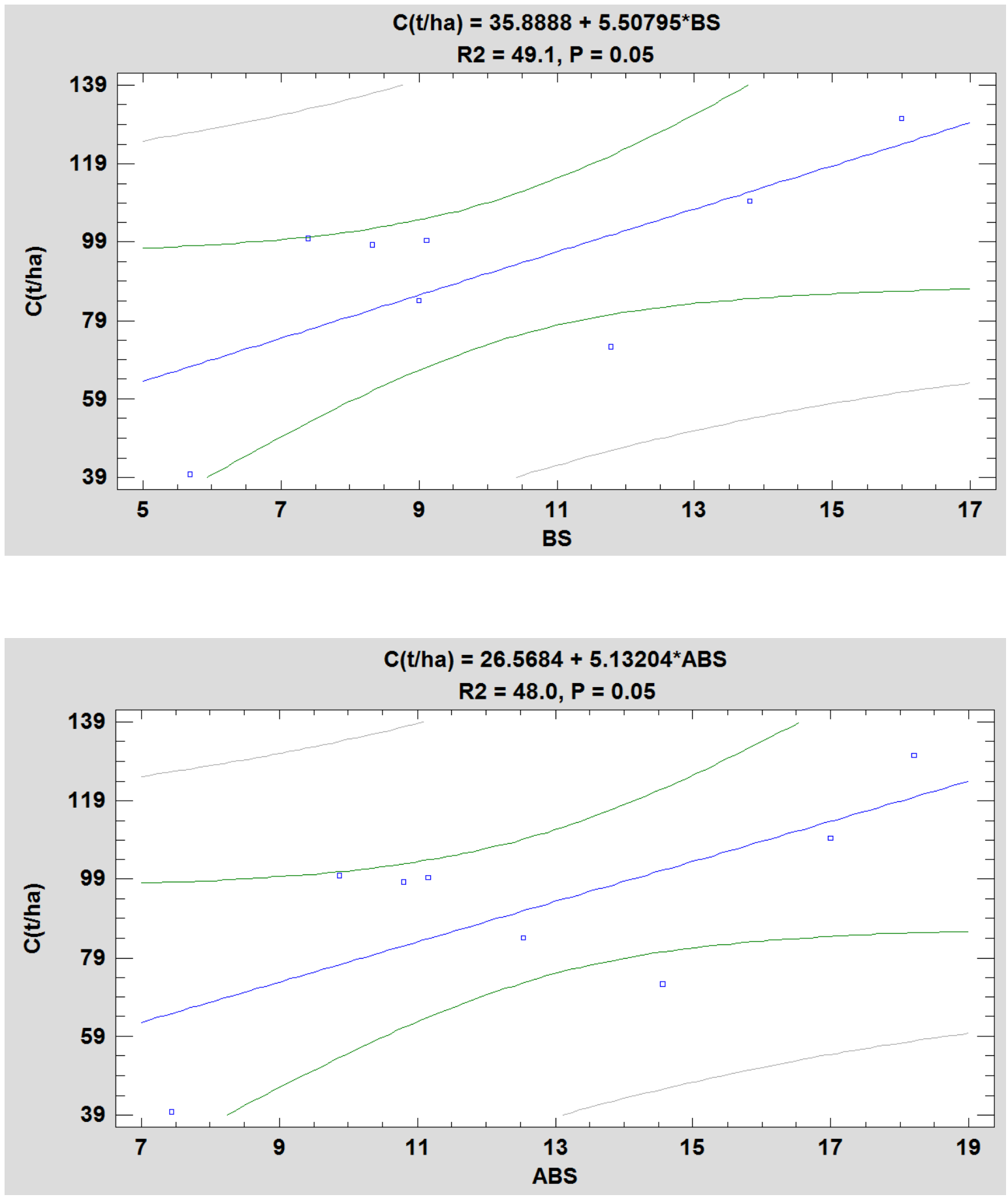

Figure 1. Relationship between the structural indexes (BS and ABS) and carbon stocks ( $M g$ ha $^{-1}$ ) in eight humid and sub-humid forests in southeastern Mexico. 

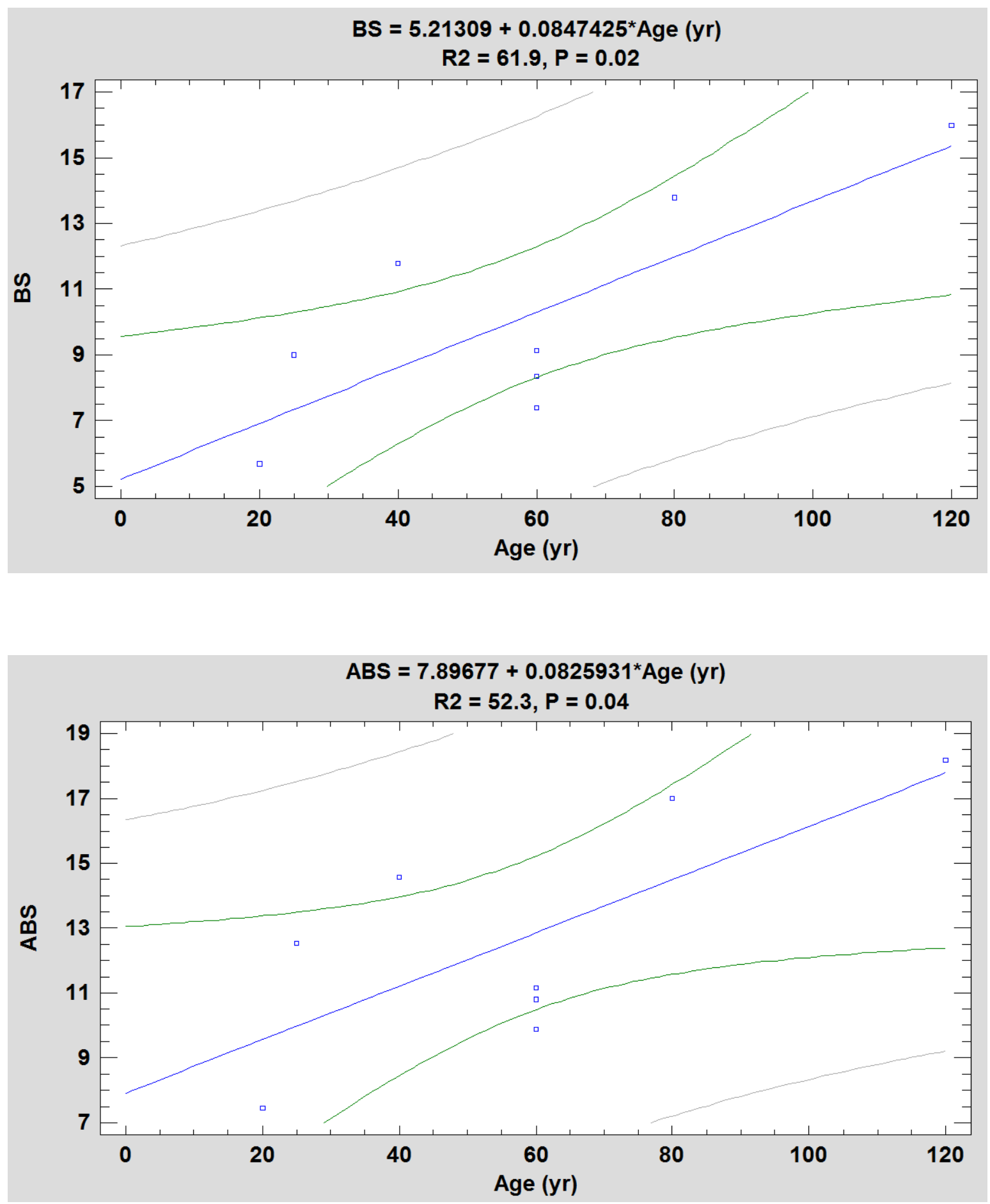


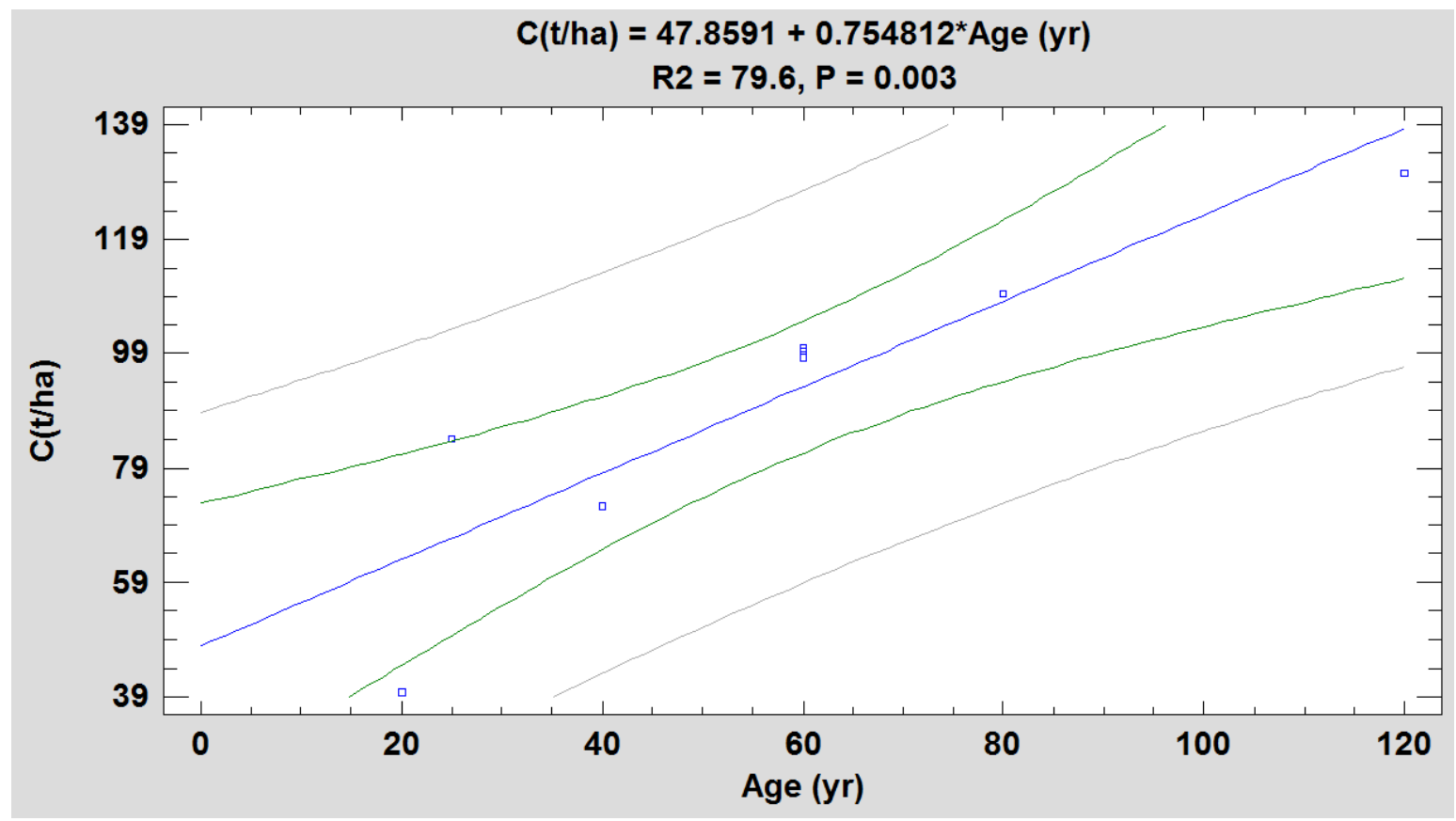

Figure 2. Relationship between stand age and structural diversity (BS, $A B S)$ and the carbon store in eight humid and sub-humid forests of southeastern Mexico. 


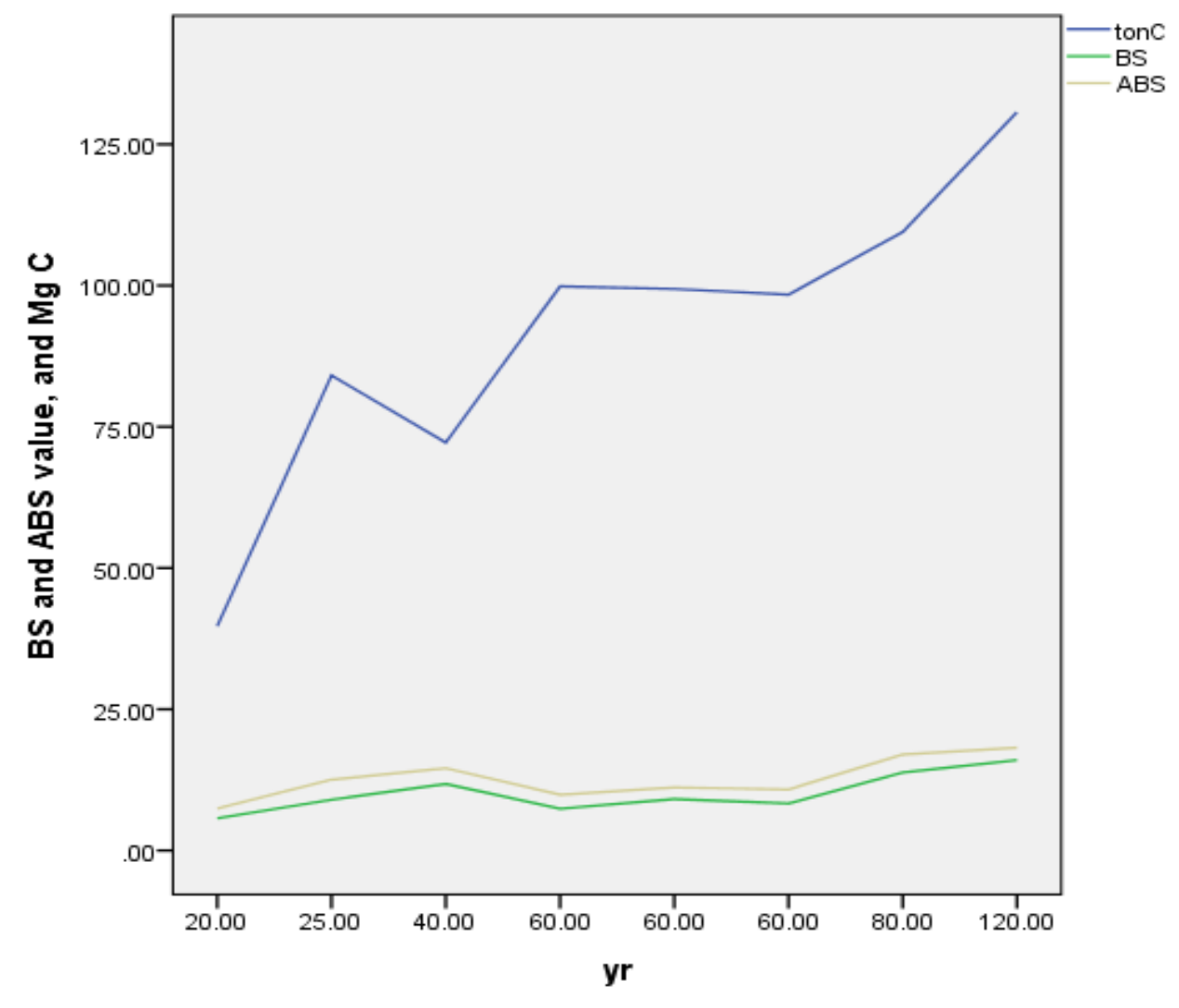

Figure 3. Change in the structural indexes BS and ABS, and carbon store with age of the stand in eight humid and sub-humid forests of southeastern Mexico.

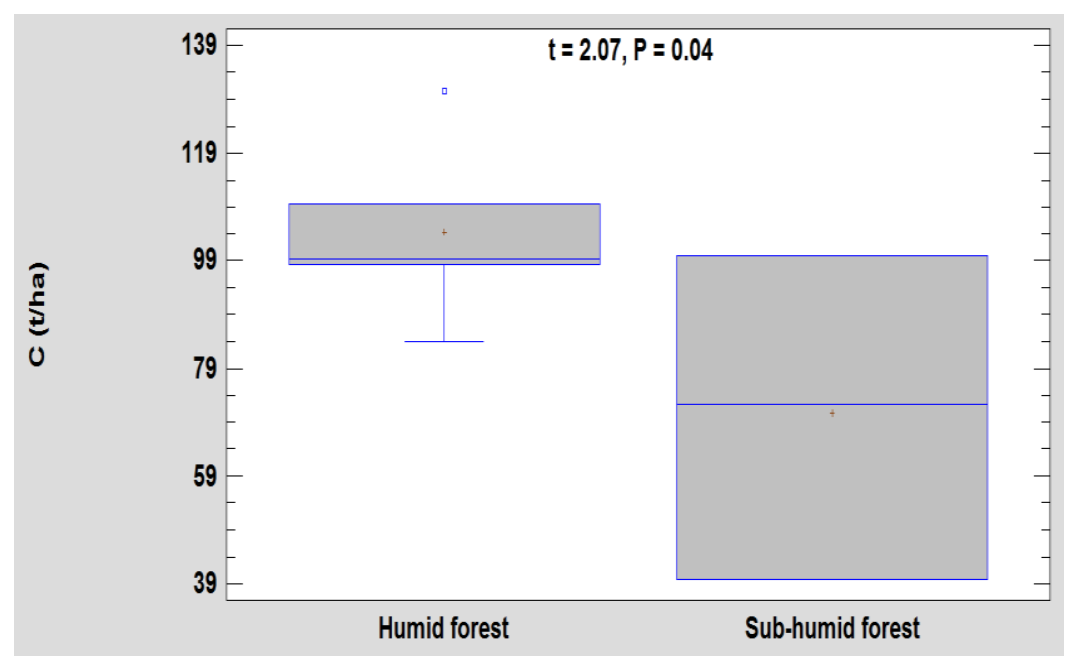

Figure 4. Comparison of means and variation of carbon stock of five humid forests and three sub-humid forests in the southeast of Mexico. 
21 February 2016

Dear editor-in Chief

Ecoscience

Following your recent correspondence, I have revised our manuscript taking into account the comments and suggestions from you and the two referees.

I would therefore like to re-submit the manuscript for publication. Title: Relationship between carbon stocks and structural diversity in humid and sub-humid tropical forest of Mexico.

We want to state that this manuscript is not under consideration for publication elsewhere and will not be submitted elsewhere while under review by Ecoscience.

Yours sincerely

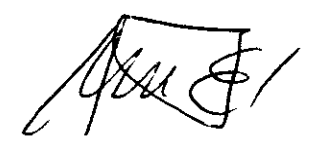

Jose Luis Martinez

First author

Correspondence email: jose.martinez@ujat.mx

Universidad Juarez Autonoma de Tabasco. Km 0.5 Carr. Villahermosa-Cardenas, Bosques de Saloya, Villahermosa, Tab. Mexico.

Phone/Fax: 52-9933-544308 